\title{
The Influence of Islamic in Ritual Shifted of Reog Ponorogo
}

\author{
Vivi Vellanita Wanda Damayanti ${ }^{1}$, Evi Muafiah $^{2}$, Jeny Casuarina Dias Safira ${ }^{3}$ \\ State Islamic Institute (IAIN) Ponorogo, Indonesia ${ }^{1}$, State Islamic Institute (IAIN) \\ Ponorogo, Indonesia ${ }^{2}$, Aisyiah University, Yogyakarta, Indonesia ${ }^{3}$ \\ \{vvellanita@gmail.com ${ }^{1}$, muafiahevi@gmail.com ${ }^{2}$, Jenny.safira@gmail.com 3 \}
}

\begin{abstract}
Ponorogo is regency in East Java province that is also known as the Reog city or Bumi Reog. For the Ponorogo society, Reog Ponorogo is one of important art that is performed in most of big ceremonials held in Ponorogo. In ancient times, there were a number of rituals and attributes used during the Reog performance. The rituals and attributes of the ceremony are believed can summon the spirits of the ancestors so that the performance of Reog can run well. It brings impacts on the high atmosphere of mysticism during the performance. Over time, the elements of mystism and rituals used to summon spirits of ancestors began to be shifted. Through interviews and observations as data collection techniques and triangulation of data as validity techniques, this qualitative study shows that the development of Islam in Bumi Reog affects changes in rituals and the elimination of mysticism in Reog performances.
\end{abstract}

Keywords: Reog; ritual; mysticism

\section{Introduction}

Ponorogo is one of the districts in East Java that has a famous cultural asset, namely Reog Ponorogo. Purwowijaya in Kardi states from emic point of view that the term of Ponorogo comes from the words pana (understand the situation) and raga (body). These two words, when are combined, have a meaning that refers to humans who already understand their body or empan papan (can place themselves). Besides that the term Ponorogo can also be derived from the word panaraga which means to exercise body (ngempanake raga) by doing some sacred efforts to approach God Almighty. On the other hand, according to the ethical view the term Ponorogo comes from the word bonorowo. Bono means scenery, and rowo meaning muddy terrain. This explains the Ponorogo landscape, which was once dominated by muddy soils.

Talking about Ponorogo, the first thing that will be remembered by the Indonesian people is about the art of Reog. Reog art has become a legendary pride, especially for the Ponorogo people. Reog art is said to be the pride of the people of Ponorogo because Reog art was born and developed in the Ponorogo area. Moreover, nowadays Reog is generally recognized as the cultural identity of the Indonesian nation Reog becomes one of the legendary arts which Indonesia had. Besides that, Reog can be a legendary, because Reog's art 
has experienced a long history. The long history of Reog's art shows that Reog's art has been tested in all eras.

Reog is an art from a Javanese Panaragan culture which has existed since the time of the Majapahit Javanese kingdom. The famousness of Reog ponorogo art is inseparable from the mystical and aesthetic elements in Reog which strongly believed by many people. This has become one of the selling points in the art performance of Reog Ponorogo. In terms of art, Reog is a native Indonesian culture, which combines mask art, theatre, music and dance. This combination of art performance is estimated to begin in Indonesia in the 12th century and its existance spread by the time. Reog Ponorogo art begins its history from the Hindhu era, the Islamic era, the colonial era, the Old Order era, the New Order era, and the Reformation era. Until now, Reog Ponorogo art is still a valuable art although some of the paradigms and staging techniques continue developed and changed from time to time.

From the history point of views, there are at least two versions of the story relating to the origin of the Reog Ponorogo. The first version of the story is a story that develops in the community, as well as contained in the Reog show itself. While the second version of the story is a philosophical and political story behind the Reog show. The official version of the Reog Ponorogo story line is the story of Raja Ponorogo who intends to propose to the daughter of Kediri King, Dewi Ragil Kuning or also known as Dewi Songgolangit. One of the requirements for an application is to make a new model of gamelan and a tiger-headed human. The gamelan is the forerunner to the Reog art at the time, it is called the gumbung. In their way to Kediri, Ponorogo King named Raja Kelono was intercepted by Singabarong King from Kediri. Singabarong King troops were consisted of peacocks and lions, while from the Kingdom of Ponorogo Raja Kelono and his Deputy Bujangganong, escorted by powerful men dressed in black. The entire dance is a war dance which was later won by the Kingdom of Ponorogo.

The second version is from a philosophical and political point of view. Pedoman Dasar Kesenian Reog Ponorogo dalam Pentas Budaya Bangsa or Basic Guidelines for Reog Ponorogo Art in the Nation Culture Stage (1996) compiled by the Ponorogo Regency Government Team tells about the origins or history of Reog Ponorogo which was originally called "Barongan" as satire from Demang Ki Ageng Kutu Suryongalam against the Majapahit King, Prabu Brawijaya V (Bhree Kertabumi). The same thing was explained by Kristianto who states that the realization of barongan was an allusion to the ruling king who had not carried out royal duties in an orderly, just and adequate manner, because the king's power was controlled / influenced even controlled by his empress (the queen of Brawijaya V).

In the Reog dance, the figure of Pujangga (poet) Anom / Bujangganong is considered a hero who philosophically represents goodness. Bujangganong is depicted as a figure with bulging eyes, which means that we have to always open our eyes eyes and read the situations to determine what is good and what is bad. Pujangga Anom's big and long nose symbolizes purity because the nose cannot be deceived, the stench will smell foul and the fragrance will smell fragrant. Its wide mouth and mrongos teeth (the upper part is slightly forward), contain advice so as not to spit words. His wide ears told us to hear good advice. In other side, the figure of Jathil symbolizes the strength and obstinacy of a soldier in powering the kingdom.

Since its creation in the 12th century, Reog has been believed using the help of magical things (supernatural) from other realms to support the show. For example, someone who carries a mask dhadhak merak, he is the one who most believed in wearing a relief of "second creature" from the invisible realm to help the show. The dhadhak merak is danced by being bitten, even though the weight of the mask ranges from 50-60 kilograms. These being the reason why people believe that the mysticism and black magic support the show. 
However, as the times evolved, Islam began to influence the art of Reog. The mysticism in Reog performance gradually changes to a ritual of cultural preservation. Ritually, forms of mysticism are still performed in Reog performances, especially Reog Obyog. While in the Reog Festival and Reog Santri performances, the ritual of mysticism has begun to be abolished. For this reason, in this article, the change of the forms of paradigm and ritual related to the mysticism issues in Reog Ponorogo which are influenced by the existence of Islam is explained.

\section{Research Methods}

The approach used in this research is descriptive qualitative. Sutopo states that qualitative research is a research in which case studies lead to a detailed and in-depth description of the condition portrait of what actually happens in the field. In this study, the focus of the research is the paradigm shift and rituals that exist in the performance of Reog Ponorogo which is influenced by the existence of Islam. The data is collected by using human instruments as the main instrument of this research. The data in this study are things related to paradigm and ritual in Reog art that changes with the development of Islam in Ponorogo. Data was collected through observation and semi structured interview techniques. The samples in this study were 2 artist and activists of art in Ponorogo and 6 Reog Ponorogo dancers with a range of 4-8 years involved in the Reog performance. All samples were males. The sample was chosen by using a purposive sampling technique because the informants were considered able to provide information relevant to the information needed.

Triangulation is used in this study as a data validity technique, whereas to test reliability, intrarater reliability and expert judgment are used. The analysis technique used in this study is the analysis technique developed by Miles and Huberman. The activity of data analysis consists of: data reduction, data display, and drawing conclusion / verification which are carried out interactively and continuously until the data are complete.

\section{Result and Discussion}

Reog Ponorogo is a dance of drama play by several dancers. Each dancer performs the dance according to the character he/ she tries to figure out. There are five figures in Reog Ponorogo, namely: (1) Singo Barong; (2) Klono Sewandono; (3) Bujangganong; (4) Jathil or Gemblak; and (5) Warok. Besides, there are three types of Reog are showed in Ponorogo. The first is Reog Baku (Reog Festival / Reog Bantarangin) which is shown on a large scale when welcoming the month of Suro (month of Shawwal / commemorating the Islamic new year). The second is Reog Street or also known as Reog Wengker/Reog Obyog. And the third is Reog santri where the show is only limited among Islamic boarding schools and not freely exhibited.

Harsono states that there is an appearance on the stage of the National Ponorogo Reog Festival Bantarangin flow exists because every Festival participant must follow the Yellow Book (Buku Kuning) instructions which was made and published by the Reog Ponorogo Foundation. While the Reog version of Wengker still exists in the community in the form of Reog Obyog show. Reog Obyog is Reog art that is asked to appear by someone or the community in an event organized by private or public. Usually they appear on order and are paid according to agreement. It could be due to circumcision, mantenan (married) and 
traditional village events, namely Bersih Desa tradition. Usually their appearance is more natural because there are no fixed rules and no judges to check their performances. Their appearance is more entertaining to the audience or who have gawe. There are usually Obyog Reog events that usually appear are Dhadhak Merak, Jathil and Bujang Ganong. In Reog Obyog show, ussualy there is only a Dhadak Merak with two Pembarongs, Jathil consists of four or more people, and one or two people as the Bujanganong. Kelono Sewandono is rarely involved or shown in Reog obyog events. The warok appears as it is without makeup like in festivals and rarely dance to the Reog Obyog tradition.

At the time of the spread of Islam in Ponorogo (circa in 1486 ) Raden Katong made Reog art as a medium for preaching to the people of Ponorogo who, at that time, were still Hindu. After Raden Katong defeated the king of Bantarangin (Ki Demang Kutu), Raden Katong then made Ponorogo a district area under the authority of the Demak kingdom. Raden Katong then held the Bathara Katong title and became Regent I. From this time, Reog was also used to spread the Islam in Ponorogo.

\section{Paradigms, Rituals and Mysticism Shifted}

Ritual or ceremony is an activity that is carried out routinely by a group of people which is applying some community laws and beliefs. This is in accordance with the opinion of Koentjaraningrat that the ritual ceremonies are a system of activation or a series of actions arranged by custom or law in force in a society that relates to how permanent events that normally occur to the community where they are belong. The ritual ceremony has rules and procedures that have been determined by the community or group of creators of the ritual, so that each ritual has a difference, both in terms of implementation or equipment. Winnick in Syam explains that ritual is a set or series of acts, usually involving religion or magic, with the sequence established by tradition.

In the Reog performance, there are rituals that must be performed as well as the ritual requirements so that the show can run well. Based on interviews conducted with two artists and art activists in Ponorogo, the ritual facilities that must be prepared before the Reog performance consist of menyan, black coffee, tamarind sugar drink, parem, sega kokoh and several others. Each of them has its own meaning which is a representation of the philosophy of local community of Ponorogo.

Sucipta, et al. revealed that the incense smoke (menyan) that was burned was a means to summon the spirits of the ancestors to be present and deign to receive offerings that have been provided to then bless it, so that people get pleasure in their lives. It was happening in the old era. But today, the symbolic of menyan mentioned above has begun to shift. In the Reog Obyog art ritual ceremony, the burning of menyan is carried out for the purpose of delivering prayers to God, not to call the spirit of ancestors anymore. While in the performance of the Reog Festival, burning menyan is no longer done.

Based on interviews done with Reog dancers, information was obtained that sometimes the burning of menyan is still carried out, but no longer to call the spirits of the ancestors but as a form of cultural preservation so that the younger generation could still see the Reog performances that were close to its original form. In addition, the Islamic religion adopted by dancers also teaches that they can only believe in one god, Allah SWT. For this reason, with or without burning the menyan, they still pray to God in hope that the performance will continue smoothly.

In addition, the form of offerings in the form of foods that were once offered to the spirits of the ancestors, are began to be interpreted in an Islamic way. Based on interviews conducted 
with two senior art activists in Ponorogo, since Islam developed, the forms of offerings have experienced a philosophical change. There are three kinds of wedangan that are often presented as a condition for Reog performances, including Wedang Kopi Hitam (black coffee), Wedang Gulo Asem (sugar-tamarind drink), and Wedang Parem. Whereas, Sega Kokoh is also a heavy food that is given. Overall, in the past was a prerequisite for the calling of ancestral spirits which is currently only given as a means of delivering Islamic da'wah and to convey philosophical values to people who have the event, performers, and the audiences in the Reog show. The philosophical values contained in it include fostering the soul of togetherness, binding of harmony, and can realize mutual cooperation. In the Reog show, the changes in values and paradigms are as follows:

The purpose of Wedang Kopi, is believed as the symbolize of Sunan Kalijaga's teachings were always reminded to set the Shari'a direction in life, that man in his journey is not always smooth but often find barriers. The symbolic meaning of this bitter coffee reminds all people involved in the performance of Reog from those who have the event, dancers, scavengers and spectators to rely on God Almighty in living their lives. The second one is Wedang Gulo Asem. Alkaf mentions that wedang gulo asem is interpreted as wedang which makes everyone who drinks it feel "kemepyar". It is symbolizing prayer and hope that is offered so that the Reog art that is displayed can be known by the wider community. When it is confirmed, two art activists Ponorogo said that its philosophical values were like that.

The third is Wedang Parem. Parem is a type of drink made from acid, turmeric, sugar and boiled salt and then the water is taken. The meaning of Wedang Parem is symbolizing that humans must feel marem (satisfied) in undergoing the weaknesses and strengths that exist in life so that they can always live in peace of mind. The last one is Sega Kokoh. The Sega Kokoh symbolizes the prosperity, for the safety of the members of the Reog arts community and the surrounding communities. Sega Kokoh is served with some components such as of tempe and tofu has a symbolic role that every human should be able to mingle with anyone in order to live prosperously and peacefully, while still being beneficial to others.

In addition to interviews conducted with two art activists in Ponorogo, interviews are also conducted with six dancers who have worked in Reog arts ranging from 4 to 6 years. From these interviews, they confirm the same thing. The existence of these foods in the Reog Festival is rarely found, except coffee which seems to be a mandatory drink for Javanese men. In Reog Obyog, these foods are still often found even though they are not in full formation. Sometimes, Sega Kokoh is replaced by other modern food menus while the wedang gulo-asem and parem are replaced by mineral water and tea. In the end they agreed that the existence of the drink was not the main factor which is supporting the success of the Reog performance. However, with the presence of these offerings they feel more proud because they feel that the community is still doing cultural prevention that is known as uri-uri budoyo. Apart from that, they also explained that actually, consciously or not, the existence of the dish symbolized the spread of Islamic values in Ponorogo because by using these offerings, there were philosophical values of goodness and divinity that were to be conveyed to the general public.

Reog began to exist in Ponorogo since around 1200 AD In the Islamic era (around 1486 AD) Raden Katong made Reog art as a medium for preaching to the people of Ponorogo who were still Hindu. After Raden Katong defeated the king of Bantarangin (Ki Demang Kutu), Raden Katong then made Ponorogo a district area under the authority of the Demak kingdom. Raden Katong then held the Bathara Katong title and became Regent I.

Since then, Reog began to be widely developed and demonstrated. Even Warok, then interpreted with the word "Wira'I" (Arabic) which means tirakat or do sacred (such as life in the jimp condition) in purpose to reach something that he/she wants. The life of this world is 
full of temptations from all directions, for that it is necessary to repent to avoid these temptations. In other hand, the Dhadak Reog is taken from the Arabic language "Riyoqun" which means Khusnul Khotimah. It can be meant that the whole journey of human life smeared with various sins and stains. When people aware and do the faithfulness and devote to the God until the end, then they can be called as a perfect human. In the Reog show, there is a mask of the Tiger (Barongan) which is haunted and haughty decorated with peacock feathers which are bluish green and shiny. Tiger mask symbolizes the evil while the peacock feathers symbolize the virtue. This reminds us that every evil will be defeated by the virtue.

From the explanation above can be known that at this time the paradigms and rituals of Reog Ponorogo have been shift. Reog is not only used as the recreation media that consist of some dancers who dance by using the black magic. In other hands, Reog is taking place as an art that is full of Islamic philosophy.

\section{Conclusion and Suggestion}

The existence of Reog as one of the national cultures originating from Ponorogo has successfully demonstrated its existence. Reog becomes a show that is often associated with old mysticism and paradigms that the show is actually full of black magic. However, in fact this is not entirely true. There has been a paradigm shift towards the Reog performance. The dishes in the form of food and drink are no longer used as a form of calling on ancestral spirits, but rather to teach philosophical values that actually indirectly represent Islamic teachings. In addition, the presence of offerings is no longer a form of spiritual means to call the ancestral spirits, but only limited to cultural preservation so that the younger generation can continue to inspire the teachings of old Java.

The sample in this study is still very limited so that this study may not be able or appropriate to be generalized in full for any form of Reog shows that are available throughout Indonesia. Therefore, further research and suggestions from readers are still highly expected for the establishment of this research also to get a more valid and credible study. 


\section{References}

[1] Achmadi, A.: Pasang Surut Dominasi Islam Terhadap Kesenian Reog Ponorogo. Jurnal Analisis Studi Keislaman, vol 8 no 1. pp. 111-134 (2013).

[2] Achmadi, A.: Aksiologi Reog Ponorogo dan Relevansinya dengan Pembangunan Karakter Bangsa. Teologia, vol 25 no 1. pp. 3-27 (2014).

[3] Alfiati: Relasi Agama Islam dan Budaya dalam Kesenian Reog Ponorogo. An-Nuha, vol 5 no 2. pp. 173-188 (2018).

[4] Alkaf, Mukhlas: Berbagai Ragam Sesajen pada Pementasan Tari Rakyat dalam Ritual Slametan. Gelar: Jurnal Seni Budaya, vol 11 no 2. pp. 211-223 (2013).

[5] Harsono, J: Hegemoni Negara terhadap Seni Reyog Ponorogo. ARISTO, vol 7 no 2. pp. 336-348 (2019).

[6] Hasanah, U., et. al.: Development of Reyog Ponorogo Traditional Theater-Based Drama Textbook (Research and Development at the Office of Education of Ponorogo Regency). International Journal of Science and Research, vol 3 no 9. pp. 2085-2094 (2014).

[7] Kardi: Literasi Budaya dan Budaya Lokal. Pustakaloka vol 5 no 1. pp. 83-91 (2013).

[8] Kencanasari, L. S.: Warok dalam Sejarah Kesenian Reog Ponorogo. Jurnal Filsafat, vol 19 no 2. Pp. 179-198 (2009).

[9] Koentjaraningrat: Kebudayaan Mentalis dan Pembangunan. PT Gramedia Pustaka Umum, Jakarta (1997).

[10] Kristianto, I.: Kesenian Reyog Ponorogo dalam Teori Fungsionalisme. Tamutra: Jurnal Seni Pertunjukan, vol 1 no 1. pp. 6-18 (2019)..

[11] Maryono: Reog Kemasan Sebagai Aset Pariwisata Unggulan Kabupaten Ponorogo. Harmonia: Jurnal Pengetahuan dan Pemikiran Seni, vol 8 no 2. pp. 158-168 (2007).

[12] Rismayanti, F. A.,et al.: Reyog Ponorogo National Festival as the Cultural Conservation Efforts and Character Education for the Younger Generation. The International Journal of Social Sciences and Humanities Invention, vol 4 no 8. pp.37683773 (2017).

[13] Riyadi, M. I., Mujahidin, A., and Tasrif, M.: Conflict and Harmoy between Islam and Local Culture in Reyog Ponorogo Art Preservation. El Harakah, vol 18 no 2. Pp. 145262 (2016).

[14] Sucipta, T., et al.: Analisis Konteks Pengetahuan Tradisional. KEMENDIKBUD, Bandung (2016).

[15] Sugiyono: Metode Penelitian Pendidikan Pendekatan Kuantitatif, Kualitatif Dan R\&D. Alfabeta, Bandung (2014).

[16] Sutopo, H. B.: Metodelogi Penelitian Kualitatif. Sebelas Maret University Press, Surakarta (2002).

[17] Syam, Nur. Islam Pesisir. PT LKIS Pelangi Aksara, Yogyakarta (2005).

[18] Tim Penulis Pem. Kab. Ponorogo: Pedoman Dasar Kesenian Reog Ponorogo dalam Pentas Budaya Bangsa. Pem. Kab. Ponorogo, Ponorogo (1996).

[19] Yurisma, D. Y., Agung, E. B. W. and Sachari, A. Kesenian Tradisi Reog Sebagai Pembentuk Citra Ponorogo. Jurnal Visualita, vol 7 no 1. Pp. 1-15 (2018). 